\title{
Satellite Observed Behavior of the Terra Nova Bay Polynya
}

\author{
DenNis D. KuRTZ and David H. BRomwich
}

Institute of Polar Studies, Ohio State University

\begin{abstract}
Infrared satellite images indicate that a polynya, surrounded by a zone of loose pack ice, persisted in Terra Nova Bay, Antarctica through the winter of 1979; the feature may recur each year. The affected region (polynya and loose pack) occupied roughly $25000 \mathrm{~km}^{2}$ of the western Ross Sea. Throughout the winter the area of open water fluctuated quasi-periodically with a period of 15-20 days. Average polynya area was $1000 \mathrm{~km}^{2}$; maximum area was approximately $5000 \mathrm{~km}^{2}$. Fluctuations were associated with the magnitude of the zonal geostrophic wind, with a closing polynya being related to strong, persistent easterlies. An open, or opening, polynya was linked with persistent westerly or weak easterly winds and the probable descent of adiabatically warming, drift-bearing air from the plateau. This air enters Terra Nova Bay through the Reeves Glacier valley, probably as katabatic surface winds. Polynya formation was probably due to the action of these winds on the coastal pack ice, while areal fluctuations reflected the interplay between the katabatic winds and synoptic scale motions advecting ice toward and away from the bay.
\end{abstract}

\section{INTRODUCTION}

Many areas of wintertime open water are now known to be present within the Antarctic northern ice limit. These play an important role in the surface energy balance of the pack ice belt [Weller, 1980] and exist on a variety of temporal and spatial scales. The Weddell Polynya is a roughly $3 \times 10^{5} \mathrm{~km}^{2}$ area of open water which irregularly forms during winter and spring [Carsey, 1980; Martinson et al., 1981]; this feature may be a result of extensive open-ocean convection [Martinson et al., 1981]. Much smaller polynyas can persist in coastal areas which are sheltered from drifting sea ice and can undergo substantial oscillations in size [Knapp, 1967, 1972; Streten, 1973]. These are distinct from shore leads which open temporarily due to seaward advection of sea ice by strong winds and which form partly by chance.

Knowledge of Antarctic coastal polynyas is limited because of the difficulty of observing small areas during the polar night. However, their extent can be approximately inferred from the $\sim 30 \mathrm{~km}$ resolution microwave brightness temperature distributions monitored since 1973 [Carsey, 1980; Weller, 1980]. Relatively high resolution $(\sim 3 \mathrm{~km})$ infrared satellite imagery permits daily observation of localized sea ice behavior throughout the winter [e.g., Dey, 1981]. The present study uses the latter to examine sea ice conditions in the western Ross Sea where a prominent feature is a polynya in Terra Nova Bay (Figure 1).

Knapp [1972], drawing on earlier work by Zubov, hypothesized that Antarctic coastal polynyas form when strong winds associated with traveling cyclones cause net sea ice displacements away from stationary ice boundaries. Thus, zonally propagating storms north of an irregular east-west coastline (East Antarctica for instance) should generate polynyas to the west of capelike projections and along the east cost of protected bays. This situation was verified by Knapp's analysis for 2 winter months of variations in the area of open water west of the fast ice anchored by Fram Bank (longitude $\sim 70^{\circ} \mathrm{E}$ ), about $70 \mathrm{~km}$ north of Cape Darnley. Knapp's model requires that for a polynya to form in Terra Nova Bay depression centers

\section{Copyright 1983 by the American Geophysical Union.}

Paper number $3 \mathrm{C} 1039$.

0148-0227/83/003C-1039\$05.00 must frequently cross Victoria Land farther south. Cyclones sometimes behave in this fashion when cyclogenesis takes place in the Victoria Land Trough [U.S. Navy Weather Service, 1970]; however, this does not explain why winter open water persists only in Terra Nova Bay. The present comparison of this polynya's behavior with synoptic scale conditions, through one winter, constitutes a needed test of Knapp's model for the geographic setting of the western Ross Sea.

Wintertime open water has been known to exist in Terra Nova Bay since 1912 when six men of Scott's Northern Party were stranded on Inexpressible Island [Priestley, 1914; Bromwich and Kurtz, 1982]. In the mid-1960's, Knapp [1972] noted this polynya in a general survey of Antarctic coastal polynyas, using experimental NIMBUS 1 and 2 infrared photographs, and gave a sequence of images illustrating its temporal variability (his Figure 6). Szekielda [1974] probably examined it more recently using early operational infrared satellite imagery. His geographic coordinates are incorrect, but the profile of the Drygalski Ice Tongue is apparent in his figure 3. Szekielda noted that the polynya persisted throughout the winter and attributed its presence to marine upwelling or submarine volcanism. The nature and frequency of polynya fluctuations and their relationships to synoptic scale weather were not discussed.

Information from sunlit periods also indicates unusual conditions in Terra Nova Bay. Sea ice charts from 1973 to present [Fleet Weather Facility, 1975, 1977, 1979; Naval Polar Oceanography Center, 1981, 1983] consistently show open water or reduced ice concentrations from October to early March. The anomaly persists in spring, surrounded by concentrated pack ice in the Ross Sea, during the summer when ice tends to remain along the Victoria Land coast, and during fall when pack ice is rapidly forming in the open sea. That the Antarctic sea ice edge retreats to its most southerly point in the central and western Ross Sea [Streten and Pike, 1980] suggests an atypical character for this whole region. Prior to 1980 , sea ice charts label Terra Nova Bay as being filled with concentrated pack from mid-March to early October. These charts were compiled on an operational basis, and sea ice conditions in that area during winter were not of navigational interest. Newer charts are more detailed. For the period between mid March and late September during the years 1980-1982, 41\% of the analyses show reduced ice concentrations or new ice in 


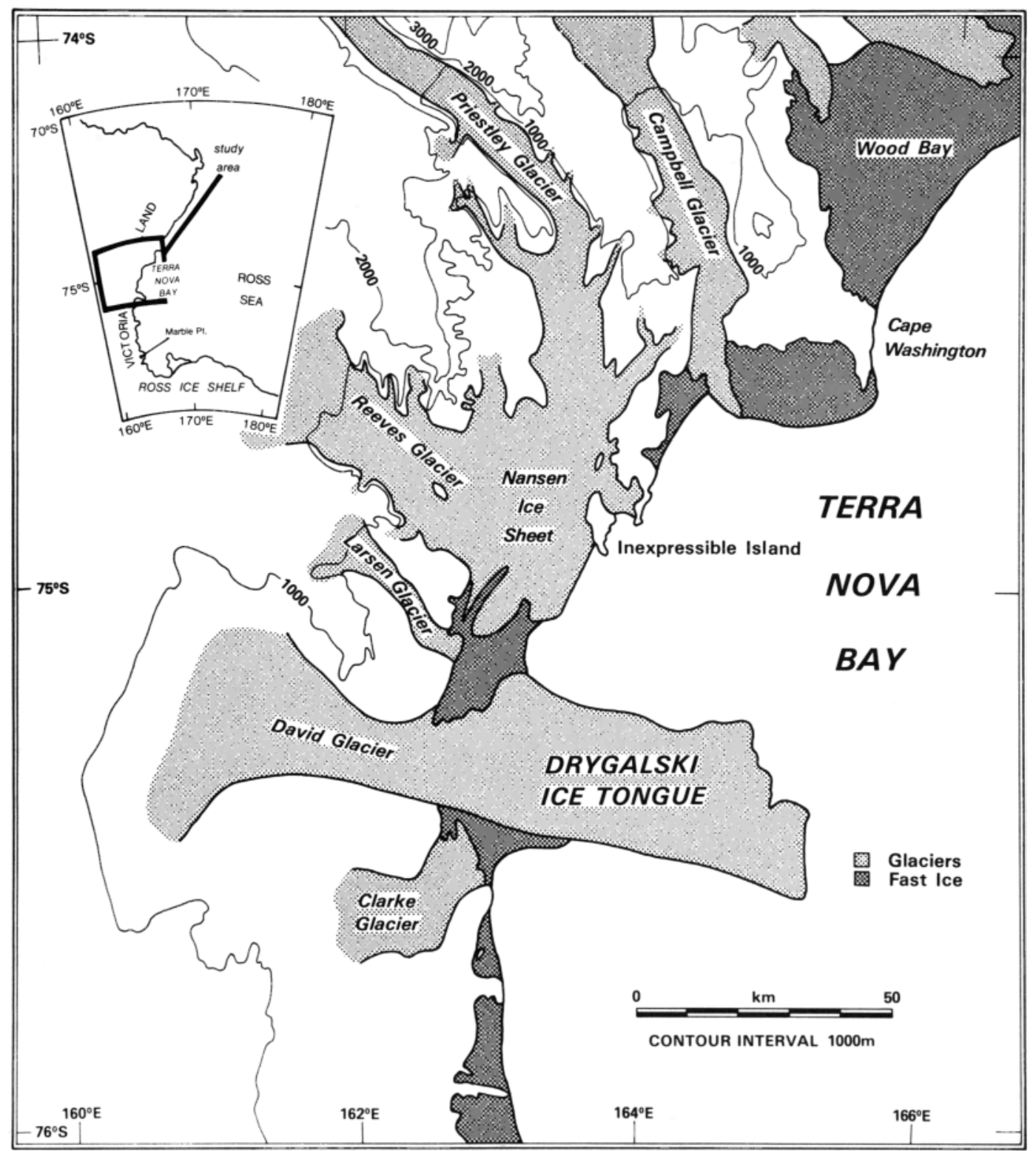

Fig. 1. Location map showing Terra Nova Bay and surrounding features.

Terra Nova Bay. These findings indicate that ice charts alone cannot be used to derive ice concentrations for the inner pack during the polar night.

Western Ross Sea wind and ice conditions were compared for March through October 1979 to elucidate mechanisms of polynya formation and maintenance in Terra Nova Bay. Sea ice behavior was monitored by using thermal infrared imagery from the two near polar-orbiting satellites administered by the U.S. Air Force Defense Meteorological Satellite Program (DMSP). Images were selected from 1979, the FGGE (First GARP Global Experiment) year, and were used in conjunction with twice-daily (0000 and 1200 GMT) synoptic analyses for that year. The latter constitute the best available record of the surface pressure field over the Southern Ocean [Guymer and Le Marshall, 1981] and enabled derivation of the western Ross Sea wind field. It is important to note, however, that the southern hemisphere circulation was highly anomalous during FGGE [van Loon and Rogers, 1981; Trenberth and van Loon, $1981]$.

\section{SATELlite IMAGERY ANALYSIS}

Infrared positive transparencies were analyzed by using straightforward photo-interpretive techniques. Original digital information was not available. Although 64 gray shades are present, the human eye can normally distinguish between about 14 shades [Dickinson et al., 1974] (i.e., objects of sufficient size with an equivalent temperature contrast of at least $7 \mathrm{~K}$ can be observed). The Drygalski Ice Tongue is a readily identifiable geographic feature on satellite images. Its profile is evident even when no open water is present. In addition, Cape Washington (Figure 1) and the outline of Terra Nova Bay usually exhibit sufficient radiative contrast with open water to be discernable. Thermal features visible on cloud-free images accurately reflect relative temperature distributions on the land, sea, or ice surface. Intervening cloud alters observed temperature, thereby modifying the appearance of the surface. But, clouds and moving features in the pack ice could be tracked by superimposing successive images, eliminating much 
TABLE 1. Estimates of Monthly Mean Extent of Open Water in the Terra Nova Bay Polynya

\begin{tabular}{lcrrrc}
\hline $\begin{array}{c}\text { Month, } \\
1979\end{array}$ & $\begin{array}{c}\text { Mean Area of } \\
\text { Open Water, } \\
\mathbf{k m}^{\mathbf{2}}\end{array}$ & \multicolumn{1}{c}{$\boldsymbol{S}$} & \multicolumn{1}{c}{$\boldsymbol{S}_{\bar{x}}$} & $\begin{array}{c}\text { Number } \\
\text { of } \\
\text { Days }\end{array}$ & $\begin{array}{c}\text { Maximum Area of } \\
\text { Open Water, } \\
\mathbf{k m}^{\mathbf{2}}\end{array}$ \\
\hline March & 3300 & 2700 & 1100 & 6 & - \\
April & 900 & 900 & 220 & 17 & 3000 \\
May & 1000 & 800 & 160 & 23 & 3000 \\
June & 1100 & 1000 & 230 & 19 & 4500 \\
July & 1100 & 600 & 120 & 25 & 3000 \\
August & 1400 & 1100 & 230 & 23 & 5000 \\
September & 1500 & 800 & 200 & 16 & 3400 \\
October & 1400 & 900 & 210 & 18 & 4500 \\
$\quad$ Total & 1300 & 1100 & 90 & 147 & 5000 \\
\hline
\end{tabular}

Values used in calculating the means are based upon minimum estimates of open water extent on any given day.

of the uncertainty associated with cloudy images. Interpretations are biased because the polynya could only be observed with cloud-free or partly cloudy conditions; however, acceptable images were available for more than half the days from March through October, 1979 (Table 1).

Discrimination between open water, consolidated sea ice, and cloud was necessary for the purposes of this study. These distinctions were possible on most images. Open water is much warmer than adjacent sea ice and thus appears darker. Sea ice, particularly old and/or thick ice, has a low surface temperature and appears light gray. It is also characterized by a network of leads and fractures wherein individual leads and crack patterns persist for 2-5 days (compare Ackley and Hibler [1977]). Sea ice boundaries are typically abrupt and roughly parallel to nearby fractures. Although clouds often have temperatures close to those of the underlying sea ice, they display curved, frequently diffuse boundaries, have an uneven texture, and are not fractured.
The most difficult distinction to make was that between open and partly open water which presumably contained patches of thin ice. The two situations differ little in temperature, and the ice cover is neither of the scale nor the thickness for a network of fractures to be visible. Thus, even when obvious open water was present, it was sometimes difficult to determine accurately its boundaries. Areas of open water were determined by projecting images onto a grid and by comparing the desired area to a known standard. Low level cloud or fog may have a similar thermal signature to that of patchy ice. However, persistence of areas designated as patchy ice for several days leads us to infer that sea surface obscuration by low level hydrometeors was not a problem.

\section{POlYNYA Description}

Terra Nova Bay is the outlet for three large glaciers (Figure 1). The floating extension of the David Glacier, the Drygalski Ice Tongue, is the southern boundary of the bay. North of this
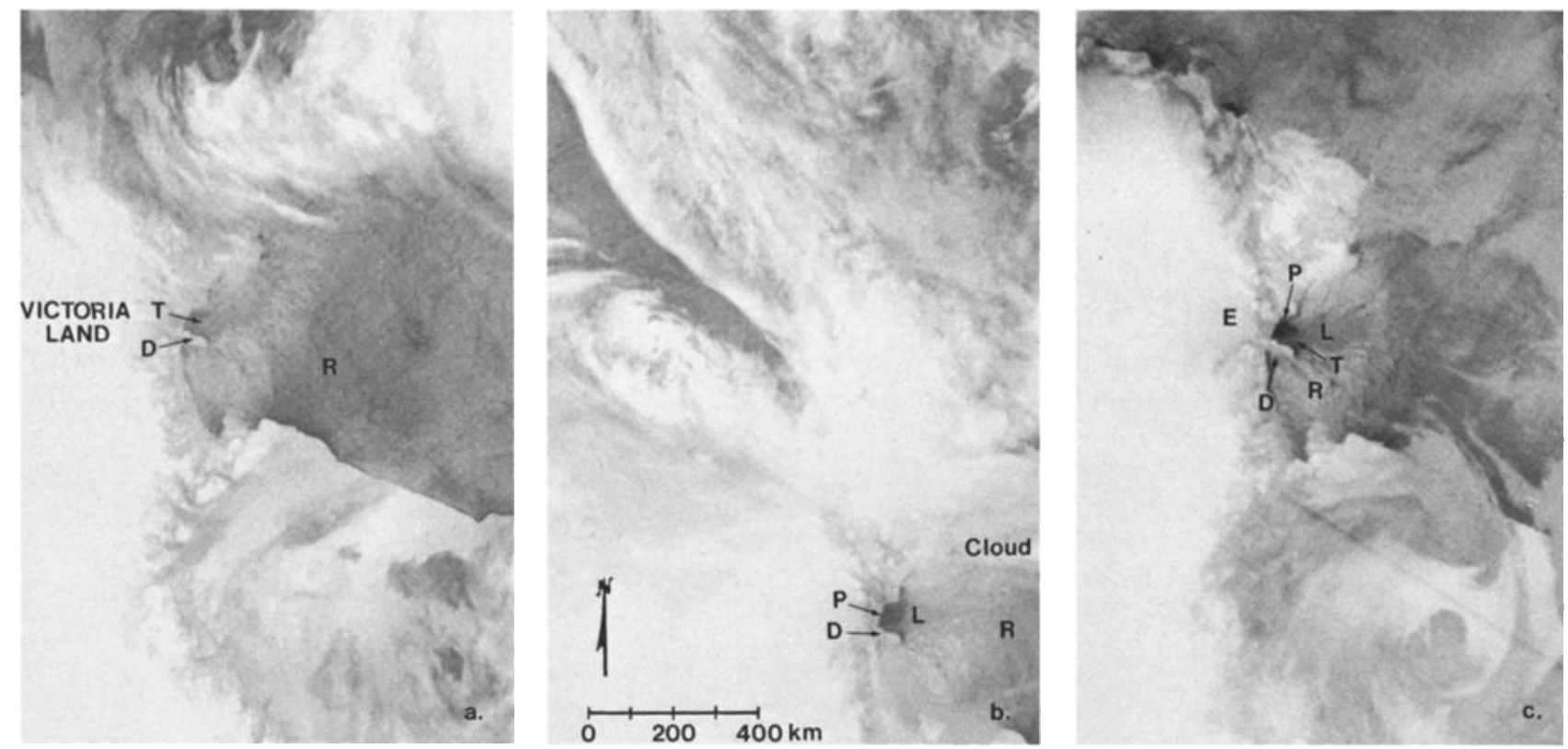

Fig. 2.(a) Infrared satellite image of western Ross Sea, September 13, 1979. Very little open water is present in Terra Nova Bay $(T)$. Light tones indicate cold temperatures, dark areas are warm. Symbols are identical throughout: $D$, Drygalski Ice Tongue; E, thermal signature of possible descending, drift-bearing air (see text); L, region of loose pack ice surrounding the Terra Nova Bay polynya (P); R, pack ice in the Ross Sea. (b) Infrared satellite image of western Ross Sea, September 16, 1979. The polynya occupies all of Terra Nova Bay. (c) Infrared satellite image of western Ross Sea, May 24, 1979. Some open water is present in Terra Nova Bay; the thermal signature of what may be descending, drift-bearing warm air is visible west of the bay. This air enters the bay through the Reeves Glacier. 


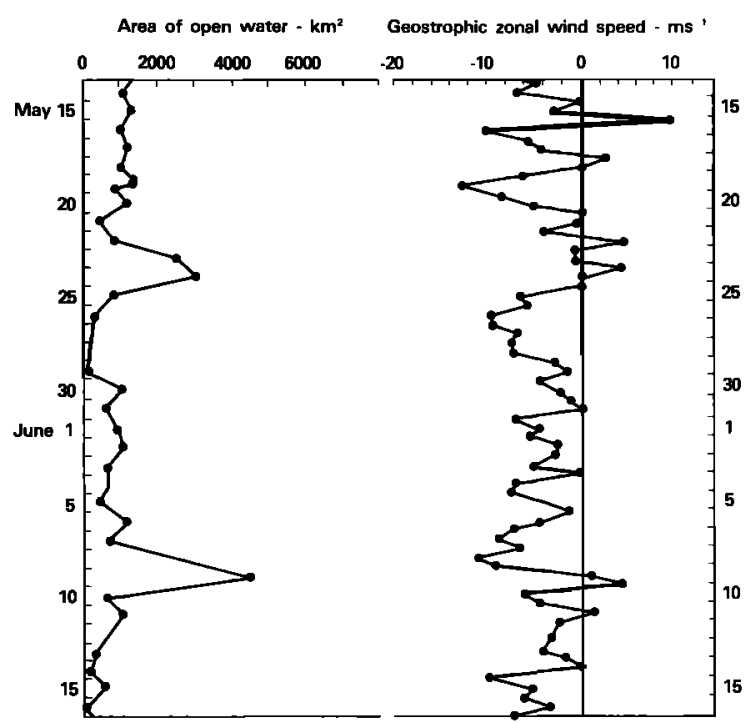

Fig. 3. Comparison of polynya area and zonal geostrophic wind, May 15 to June 15,1979 , representative of the entire winter.

the Reeves and Priestley glaciers converge as the Nansen Ice Sheet, whose calving wall forms much of the bay's western border.

The unusual conditions which influence the Terra Nova Bay polynya apparently affect a large region in the western Ross Sea. This affected area is divisible into two zones. The polynya itself is the area of open water closer to the coast. A larger region of patchy or thin ice surrounds the polynya on its seaward sides, being bordered on the south by the Drygalski Ice Tongue. Sea ice there appears featureless on infrared images, in contrast to the fractured Ross Sea pack. This featureless zone is lighter in tone (colder) at greater distances from the open water. A concentric arrangement of sea ice and open water was also described by Szekielda [1974]. The northern boundary of the affected zone is diffuse, but the eastern edge is marked by a band of cold, fractured sea ice. Fractures are organized in a radial pattern centering on the polynya and extending into the consolidated Ross Sea pack ice.

The polynya fluctuates in size from a minimum, when almost no open water is visible (Figure 2a), to conditions where all of Terra Nova Bay is open (Figure $2 b$ ). Maximum wintertime polynya area is approximately $5000 \mathrm{~km}^{2}$. The western portion of the bay, immediately east of the outlet of the Reeves Glacier (Figure 1), is normally open. Maximum polynya width appears to be controlled by the length of the Drygalski Ice Tongue. Wintertime open water never extends very far east of it. The region of patchy and thin ice surrounding the polynya extends north and east of Terra Nova Bay (Figure $2 c$ ) and occupied a maximum area of approximately $25000 \mathrm{~km}^{2}$. Its shape probably reflects the distribution of conditions which, while not able to maintain open water, nevertheless prevent sea ice from consolidating. This zone of partial ice cover undergoes areal fluctuations in phase with those of the polynya, but does so to a lesser degree.

Satellite images also record thermal features on land which may be related to polynya conditions. The relatively warm region visible west of Terra Nova Bay in Figure $2 c$ occurs only along this portion of the western Ross Sea coast. This phenomenon is not always present, suggesting some meteorological control; its shape and internal thermal structure close- ly parallel ice surface topography, implying a physiographic influence. The signature may reflect the presence of descending, adiabatically warming air which is transporting drift. Infrared satellite imagery has been used to observe strong valley winds in Alaska [Marvill and Jayaweera, 1975]. This feature appears to enter into Terra Nova Bay through the Reeves Glacier valley and is commonly associated with an open, or opening, polynya. Moderate to strong persistent winds were observed to blow from this valley by the men of Scott's Northern Party in 1912 [Bromwich and Kurtz, 1982]. The high frequency of intermediate speeds and the unidirectional character of that wind suggest a katabatic origin. Strong, persistent, jetlike katabatic outflow is suggested by Parish's [1982] simulation which shows a pronounced confluence (from $\sim 3 \%$ of East Antarctica) of winter surface winds on the ice sheet inland from the bay. Typically, katabatic winds die out within a few kilometers beyond the foot of the terrain slope [Schwerdtfeger, 1970]. Here, by contrast, the strong winds extend at least to Inexpressible Island, about $25 \mathrm{~km}$ eastward of the slope break, and probably well beyond that. The dynamical basis for this situation will be discussed in a subsequent paper. The wind was assumed by the Northern Party to be responsible for the failure of sea ice to consolidate in the immediate vicinity of Inexpressible Island, and this is supported by our analysis of their descriptive observations [Bromwich and Kurtz, 1982]. The present analysis attempts to determine the relative influence of synoptic scale weather and katabatic outflow on polynya behavior.

\section{Polynya Fluctuations}

Areal variations of the Terra Nova Bay polynya were compared with the zonal component of the estimated surface geostrophic wind to examine the relationship between synoptic scale forcing and polynya behavior. The geostrophic wind was taken to indicate direction of sea ice movement; the following analyses support this approach. Brown [1981] noted that the (frictionally retarded and deflected) surface wind blows over the wintertime pack ice of the Beaufort Sea at an average angle of $30^{\circ}$ to the left (looking downwind) of the isobars. According to Knauss [1978], Nansen, while frozen in the Arctic pack, observed that when the wind blew the ice appeared to move at an angle of $20^{\circ}-40^{\circ}$ to the right of the wind. The geostrophic wind is a good approximation to the free atmospheric flow when the pressure field is slowly varying and fairly uniform and where the fetch is relatively large. Then, if the wind-induced ice drift is much larger than the current drift, sea ice moves in the direction of the surface geostrophic wind. Further support comes from the recent empirical investigation of Arctic sea ice motions by Thorndike and Colony [1982]. They found that, within $400 \mathrm{~km}$ of the coast, the complex number equation

$$
u-\bar{c}=0.008 e^{-i 5^{\circ}} G
$$

explains roughly $50 \%$ of the variance in winter and spring sea ice motions on time scales of from 1 to 30 days. The expression on the left is the wind-induced sea ice velocity, overall ice movement $(u)$ minus the mean ocean current $\bar{c}$. The angular difference between this movement and the geostrophic wind $(G)$ is $5^{\circ}$ to the right, and ice moves at $0.8 \%$ of the speed of $G$. In the absence of any in situ measurements, a similar momentum balance is assumed for the Ross Sea pack in spite of the likely differences in atmospheric stability, surface roughness, and pack ice characteristics. However, the directions of 
Coriolis force, frictional deflection of the geostrophic wind, and sea ice movement relative to the geostrophic wind are opposite to those in the northern hemisphere.

The geostrophic wind vector was estimated by measuring average orientation and spacing of isobars over the Ross Sea within a 100 to $200-\mathrm{km}$ radius of Terra Nova Bay on the twice daily mean sea level pressure analyses produced by the Australian Bureau of Meteorology, Melbourne. Geostrophic wind speed $V_{g}$ was calculated from the formula

$$
V_{\theta}=\left(\alpha / f_{75}\right)(\Delta p / \Delta N)
$$

where $f_{75}$ is the Coriolis parameter evaluated at $75^{\circ} \mathrm{S}, \Delta p$ is the pressure difference across which the normal isobar spacing $\Delta N$ was measured, and $\alpha=(R T / p)$ where $R$ is the gas constant for dry air and $p$ and $T$ are the climatological monthly average surface pressure and temperature at $75^{\circ} \mathrm{S}, 165^{\circ} \mathrm{E}$ [Taljaard et al., 1969].

Frictional deflection and retardation of the winter surface geostrophic wind for the Beaufort Sea [Brown, 1981] were used to estimate the surface wind over the Ross Sea from the geostrophic values. The vector resultant of these estimates for the period from March through October 1979 was from $176^{\circ}$ at $4.2 \mathrm{~m} \mathrm{~s}^{-1}$ with a directional constancy of 0.85 . About $90 \%$ of the wind directions lay in the quadrant between southeast and southwest. Thus, most of the estimated surface winds blew in a direction roughly parallel to the coastal mountains west of Terra Nova Bay. Automatic weather station measurements of the March-October surface wind at Marble Point (Figure 1) during 1980 and 1982 provide comparative data. The wind regime there, about $300 \mathrm{~km}$ due south of Inexpressible Island, is dominated by large-scale effects. The 1980 (1982) resultant wind vector was from 192 (198) degrees at 2.9 (2.3) $\mathrm{m} \mathrm{s}^{-1}$ with a directional constancy of $0.70(0.69) ; 69 \%$ of the observed wind directions fell in the quadrant between southeast and southwest. Here again, most of the winds blew roughly parallel to the Transantarctic Mountains. It is contended that the similarity between the observed and derived wind records, despite differing observation periods and spatial separation of the sites, lends credibility to the pressure analyses from which the 1979 surface winds were estimated. This situation is also consistent with the possible presence of frequent, southerly, wintertime barrier winds blowing parallel to the Transantarctic Mountains [Schwerdtfeger, 1979] over the western Ross Sea.

Ninety percent of the estimated geostrophic winds were from directions between east and south. Strong westerlies were infrequent. Polynya areal fluctuations occurred quasiperiodically, with a period of 15-20 days (Figure 3), and appear to be related to changes in the geostrophic wind field. An opening or extensive polynya was concurrent with or immediately preceded by winds with marked westerly or weak easterly components. Rapid decreases in polynya area were usually associated with relatively strong easterly winds (zonal component $>6 \mathrm{~m} \mathrm{~s}^{-1}$ ). Some correlation between the area of open water and the zonal wind component is expected because polynya area varies principally by the east-west migration of its eastern boundary. However, correlation between the two is low $\left(r_{z}=0.30\right)$ though significantly greater than zero (at the $0.1 \%$ confidence level). Best correlation is exhibited with zero lag. No correlation between polynya area and the meridional geostrophic wind is expected or present at the 5\% confidence level $\left(r_{m}=0.15\right)$. The low $r_{z}$ value suggests that polynya area varies only partly in response to the strength and direction of the zonal wind. Duration of changes in the wind field may also influence polynya response. Marked changes of short duration appear to have little effect. Changes in the wind field eliciting major changes in polynya ice conditions are of fairly long ( $>36$ hours) duration. Also, maximum polynya area is also controlled by the length of the Drygalski Ice Tongue which determines maximum polynya width.

The polynya was seldom if ever eliminated by synoptically driven sea ice advection, indicating that other phenomena are responsible for its presence. Table 1 shows monthly mean polynya areas for March-October 1979. Average area of open water in March is quite large, but, owing to the initial formation of a definite polynya during that month, it does not reflect the magnitude of the physical processes involved. The polynya was well defined by April, with polynya area remaining constant from April through July. A polynya area of roughly $1000 \mathrm{~km}^{2}$ probably reflects the magnitude of wintertime processes that influence its formation. Increasing area coincides with increasing solar insolation; sunrise at $75^{\circ} \mathrm{S}$ is on August 10.

\section{CONCLUSIONS}

Polynya fluctuations in Terra Nova Bay were associated with a variety of synoptic situations. These included western Ross Sea lows traveling from south to north and north to south; cyclones originating at various points along the Victoria Land coast; and, most frequently, troughs connected with depressions moving eastward across the Ross Sea entrance. Thus, though Knapp's model provides a convincing explanation for synoptically forced polynyas along the East Antarctic coast [Knapp, 1972] and in the western Weddell Sea [Kyle and Schwerdtfeger, 1974], more complex and varied synoptic sequences occur in the western Ross Sea. These considerations and the low, but significant, correlation between polynya fluctation and zonal geostrophic wind indicate that synoptic scale motions, by their associated sea ice advection, only modify polynya extent.

The principal influence on polynya formation and maintenance is probably persistent katabatic winds that remain stable for tens of kilometers beyond the coastal slope break. Their magnitude is reflected by the $1000 \mathrm{~km}^{2}$ average polynya size during the polar night; synoptically driven areal fluctuations at times exceed $2500 \mathrm{~km}^{2}$. The nucleus of open water near the Reeves Glacier, wind observations in 1912, and Parish's [1982] simulation support this hypothesis. Furthermore, rapid sea surface freezing was observed during calm intervals by the Northern Party [Bromwich and Kurtz, 1982], indicating that bay waters will freeze in the absence of katabatic winds regardless of the geostrophic windfield. The combination of katabatic persistence and stability is anomalous and fundamental for annual formation of the Terra Nova Bay polynya. Typical katabatic winds, experiencing katabatic jumps [Ball, 1957; Parish, 1981], would dissipate much of their energy near the coast and would not affect sea ice conditions great distances offshore.

Acknowledgments. We thank Terri Gregory of the DMSP Library, Space Science and Engineering Center, University of WisconsinMadison for valuable assistance. Collection of the Marble Point meteorological observations was supported by NSF grant DPP7925040 to Charles R. Stearns. This work was supported in part by NSF grant DPP-8100142 and is contribution 470 of the Institute of Polar Studies, The Ohio State University. 


\section{REFERENCES}

Ackley, S. F., and W. D. Hibler, Measurements of Arctic Ocean ice deformation and fracture patterns from satellite imagery, in Polar Oceans, edited by M. J. Dunbar, pp. 227-238, Arctic Institute of North America, Calgary, Alberta, 1977.

Ball, F. K., The katabatic winds of Adélie Land and King George V Land, Tellus, 9, 201-208, 1957.

Bromwich, D. H., and D. D. Kurtz, Experiences of Scott's Northern Party: Evidence for a relationship between winter katabatic winds and the Terra Nova Bay polynya, Polar Rec., 21, 137-146, 1982.

Brown, R. A., Modeling the geostrophic drag coefficient for AIDJEX, J. Geophys. Res., 86, 1989-1994, 1981.

Carsey, F. D., Microwave observation of the Weddell Polynya, Mon. Weather Rev., 108, 2032-2044, 1980.

Dey, B., Monitoring winter sea ice dynamics in the Canadian Arctic with NOAA-TIR images, J. Geophys. Res., 86, 3223-3235, 1981.

Dickinson, L. G., S. E. Boselly, and W. S. Burgmann, Defense Meteorological Satellite Program (DMSP) user's guide, Rep. AWS TR-74-250, Air Weather Serv., Scott AFB, Ill., 1974.

Fleet Weather Facility, Antarctic Ice Charts, 1973-1974, Suitland, Md., 1975.

Fleet Weather Facility, Antarctic Ice Charts, 1975-1976, Suitland, Md., 1977.

Fleet Weather Facility, Antarctic Ice Charts, 1977-1978, Suitland, Md., 1979.

Guymer, L. B., and J. F. Le Marshall, Impact of FGGE buoy data on southern hemisphere analyses, Bull. Am. Meteorol. Soc., 62, 38-47, 1981.

Knapp, W. W., Formation, persistence and disappearance of open water channels related to the meteorological conditions along the coast of the Antarctic continent, in Polar Meteorology, Tech. Note 87, pp. 89-104, World Meteorol. Organ., Geneva, Switzerland, 1967.

Knapp, W. W., Satellite observations of large polynyas in polar waters, in Sea Ice, edited by T. Karlsson, pp. 201-212, National Research Council, Reykjavik, Iceland, 1972.

Knauss, J. A., Introduction to Physical Oceanography, p. 122, PrenticeHall, Englewood Cliffs, New Jersey, 1978.

Kyle, T. H., and W. Schwerdtfeger, Synoptic scale wind effects on the ice cover of the westen Weddell Sea, Antarctic J. U.S., 9, 212, 1974.

Martinson, D. G., P. D. Killworth, and A. L. Gordon, A convective model for the Weddell Polynya, J. Phys. Oceanogr., 11, 466-488, 1981.

Marvill, S., and K. O. L. F. Jayaweera, Investigations of strong valley winds in Alaska using satellite infrared imagery, Mon. Weather Rev., 103, 1129-1136, 1975.

Naval Polar Oceanography Center, Antarctic Ice Charts, 1979-1980, Suitland, Md., 1981.
Naval Polar Oceanography Center, Antarctic Ice Charts, 1981-1982, Suitland, Md., 1983.

Parish, T. R., The katabatic winds of Cape Denison and Port Martin, Polar Rec., 20, 525-532, 1981.

Parish, T. R., Surface airflow over East Antarctica, Mon. Weather Rev., 110, 84-90, 1982.

Priestley, R. E., Work and adventures of the Northern Party of Captain Scott's Antarctic Expedition, 1910-1913, Geogr. J., 43, 1-14, 1914.

Schwerdtfeger, $\mathbf{W}$., The climate of the Antarctic, in Climate of the Polar Regions, edited by H. E. Landsberg, pp. 253-355, World Survey of Climatology, vol. 14, Elsevier, New York, 1970.

Schwerdtfeger, W., Meteorological aspects of the drift of ice from the Weddell Sea toward the mid-latitude westerlies, J. Geophys. Res., 84, 6321-6328, 1979.

Streten, N. A., Satellite observations of the summer decay of the Antarctic sea ice, Arch. Meteorol. Geophys. Biokl., Ser. A, 22, 119 $134,1973$.

Streten, N. A., and D. J. Pike, Characteristics of the broadscale Antarctic sea ice extent and the associated atmospheric circulation 1972-1977, Arch. Meteorol. Geophys. Biokl., Ser. A, 29, 279-299, 1980.

Szekielda, K. H., The hot spot in the Ross Sea: Upwelling during wintertime, Tethys, 6, 105-110, 1974.

Taljaard, J. J., H. van Loon, H. L. Crutcher, and R. L. Jenne, Climate of the upper air, Southern hemisphere, vol. 1, Temperature, dew points, and heights at selected pressure levels, Rep. NAVAIR-50IC-55, Naval Weather Serv. Command, Washington, D. C., 1969.

Thorndike, A. S., and R. Colony, Sea ice motion in response to geostrophic winds, J. Geophys. Res., 87, 5845-5852, 1982.

Trenberth, K. E., and H. van Loon, Comment on "Impact of FGGE buoy data on Southern Hemisphere analyses," Bull. Am. Meteorol. Soc., 62, 1486-1488, 1981.

U.S. Navy Weather Service, Antarctic Forecaster's Handbook, Antarctic Support Activities, Detachment Charlie, New York, 1970.

van Loon, H., and J. C. Rogers, Remarks on the circulation over the southern hemisphere in FGGE and on its relation to the phases of the Southern Oscillation, Mon. Weather Rev., 109, 2255-2259, 1981.

Weller, G., Spatial and temporal variations in the south polar surface energy balance, Mon. Weather Rev., 108, 2006-2014, 1980.

D. H. Bromwich and D. D. Kurtz, Institute of Polar Studies, Ohio State University, Columbus, OH 43210.

(Received January 14, 1983; revised March 22, 1983; accepted June 16, 1983.) 